\title{
Marketing in Insurance Industry, Marketing Functions in Insurance Industry
}

Besnik Zekaj

PhD Cand.Faculty of business, Public University "Haxhi Zeka"- Peja, Kosovë

\begin{abstract}
According to the logic of economic laws of market economy, the existence of enterprises is determined by it as to organize and realize the sale of their products and services. So, insurance companies or companies in this case can only exist if developed, increasing their activities in the field of insurance services that offer their clients. The need for marketing development in the field of insurance as service activities, in economic conditions of today's market it is necesery increase, so even the functioning of the insurance market today depends on the marketing of products that insurnace companies offer customers through insurance market. In theoretical terms it is defined as the marketing concept of the market, management and leadership in the company, which instead of former production orientation, the orientation of the market inaugurates the general policy of the enterprise. Marketing plays a key role in insurance market to meet supply and demand, because insurance products are products that are not seen, not touched, but exist only in the form of pledges. Selling a promise requires a confidence, a belief that the service provider will be realized if the loss will occur. In any other economic or economic subject, whether manufacturer or service does not have such kind of product. Marketing insurance plays a manifold, on the one hand made product promotion security, then raise the awareness of citizens about models of protection from risks, increased reliability to consumers, the cost of paying for the promise given by the insurer if a loss occurs will accomplished.
\end{abstract}

Keywords: Marketing in Insurance Industry, Insurance Market, Insurance Company.

\section{Introduction}

Modern economy is characterized by the free market, which means that business activities and economic generally are associated exclusively with the market. On the market are two main mechanisms: Market supply and demand. Demand in the market is found to consumers (individual, household, enterprise), while formed in the enterprise offering, in order to meet customer requirements. Who meets answer the request or needs, it is clear: demand meets supply.

Production of goods and services has given birth to the degree of development of the productive forces of social development, previously Marketing has only assisting function, where most of the production enterprises key problem was not selling products. In this regard, the directors of enterprises to be more engaged improved production techniques since the most difficult was to to produce than the market alocation. Activities that today are known as marketing by the end of the nineteenth century were named as sales, also after the First World War the sale was the main concern of enterprises, formed society of consumption where manufacturers offer unlimited amounts of products on the market, while consumer it was rare. This step marks the birth of advertising and marketing since 1950 has a modern approach to solving problems in a complex way within the enterprise, where these activities are achiveable and beneficial.

The term marketing summarizes the philosophy business enterprise, institution or individual that characterizes concentration, or focus on the customer, expressed through the effort of permanent and harmonious whole enterprise, in the process of fulfilling the needs and wishes of the customer and its implementation enterprise objectives.

The purpose and mission of each enterprise is customer satisfaction. The fact that the meaning of key concept of marketing focus to consumers, any business entity that is engaged in the manufacture of products and services, to be successful you never dare to forget that in a market economy free customer is king and according to this companies also have adopted different market offers. 
Marketing in the insurance market plays a key role to meet supply and demand, because insurance products are products that are not seen, not touched, but exist only in the form of pledges. Selling a promise requires a confidence, a belief that the service provider will be realized if the loss will occur. In any other economic or economic subject, whether manufacturer or service does not have such kind of product. Marketing insurance plays a manifold, on the one hand made product promotion security, then raise the awareness of citizens about models of protection from risks, increased reliability to consumers, the cost of paying for the promise given by the insurer if a loss occurs will accomplished.

This paper is composed hereafter practical examples of various forms of promotional marketing that make enterprises insurance company through forms of compartmentalisation advertising transmitted in the print and electronic (television , radio , newspapers, magazines , billboards, internet, flyers, etc.).

The findings and recommendations are an important part of this work by giving opinions about forms of marketing and the role that marketing in the development and advancement of insurance companies, thereby attempting to convince people that every company wants to win over rivals his.

Marketing and its element in insurance industry

The combination of supply and demand for these products can not be believed without any regulatory mechanism. Main market regulator. The insurance market is one of the most developed markets and most powerful in the world .It is characteristic of this market is that increasing the number of insured will not affect the reduction or increase of premiums. "Marketing can be defined as the process of planning and realization of the concept, pricing policy, promotion and distribution of ideas, and services for asset swap, which meet individual and organizational goals"

Marketing strategy operacionaliziohet through segmentation and selection of markets desired, which means the process of division of the total market of insurers in homogeneous groups of the insured, who between them are distinguished according to their needs, so choose segments which sigurusit will provide services. When it comes to marketing in insurance marketing as diciplin then scientific thought and understood as the conception of the work in the field of insurance. Such an approach requires the construction of a unique marketing your strategy and integration within comprehensive insurance. Utilizing marketing concept in the insurance market is the research of the insurance market are defined as synonymous marketing research. Insurance market most often explored:

Capacity of the market

\section{Range of insurance types;}

3. Market development oportunities;

4. Distribution;

5. Market prices.

The participants in insurance industry are:

1. The Insured (individuals, families, businesses, society etj.),

2. Insurance intermediaries (agetns, brokers etj),

3. The Insurer (the coverage provider),

4. User (compensatet claim).

The specificity of the insurance market is that insurance product created itself on providing contract, which means selling that product. To say that this is the specific area of insurance when considering their economic activity and by product (services) offered by the insurer (insurance company) insurance market. Insurance company - insurer, in this case sells "safety", to which the insured during his business realizes the fulfillment of obligations taken on those economic entities to which the insured is realized. Unlike other manufacturers of goods, in insurance there is no possibility of establishing inventories of products. 
Insurer might produce 10,000 "cheap" policies to market if we assume that this is its capacity, as it can be a producer of other goods. But the insurer may extend the sale directly to the required size. In practice insurance market segmentation realized by geographic, demographic, economic and other aspects, namely by other criteria. Each of these criteria has its own characteristics, which is why it's so specificaly defined, and defined so is used in the insurance market segmentation. All this is accomplished with the aim of practical benefit from market segmentation, in order to be placed as well on the services provided.

\section{Marketing Elements in the Insurance market}

The insurance market is specific because the products that are sold and specific customers. Marketing in the insurance market is comprised of four core elements: Products, Price, Distribution and Promotion

\section{Products}

Insurance products in the region are homogeneous, any introduction of new product in market requires the development of a long-term insurance products because they have a high cost expenditure. Beliefs of consumers for these products are long-term civic obedience. Convince consumers to purchase these products, it requires reliability, which is one of the main components in the insurance market. Also insurance product range quite prosperous. It is assumed that by now are over 90 insurance products in developing countries a high classification of insurance required by international standards, and most have a low development party insurance homogeneous products. This is because the introduction of new products is very high cost.

\section{Price}

The most important component in the insurance market is the price of the service or product offered by the insurer. To manage risk taking must have tools. Insurance companies provide the means of price policy, or premium, which in itself contains functional and the premium which serves to cover the costs of directing. On premise pricing should know that what serves as the basis for calculating the premium. (Net premium) or functional Premium is part of the premium that would cover losses and expenses with estimated losses. (Gross premium) includes net premium or functional as well as directing or operational costs.

The premium is the price quotes for insurance unit. Security Unit can be quite complicated, which subordinates insurance product that is the word, for example in the provision of fire it can be a building cover 150,000.00 euro, while measuring the production unit will be the value of production for the sales clerk insurance unit that done. Vehicle insurance to insurance unit is provided vehicles for a year. In determining the premise quota should keep in mind that one way to attract customers from the other side must keep in mind the definition of the premium, because low premium may lead to the insurance company in bankruptcy. So to set the price of an insurance policy expert engage various fields using different methods statistical probability accounts, dynamic analysis, methods that are inaccessible to the customer.

\section{Distribution}

Distribution of insurance products is done through direct and indirect channels. Direct channels in the insurance market are insurers who themselves develop strategic policies to ensure long-term civic and market development, using various methods of economic propaganda, economic publicity etc. In order to keep close relationship between the insured and the insurer, the insurer uses indirect channels for placing products using many agents, brokers etc.

\section{Promotion}

It is a process of communication between providers and consumers in order to create a positive conviction for products and services offered by the insurance market. The promotion is a permanent process of communication by insurane providers for existing and potential customers according to Kotler "Promotion includes all the tools of marketing system, whose task is to communicate with potential buyers." Besides the offer more attractive, sales of insurance products often depends from different communities, whether external or internal. Good communication with the customer company adds beliefe because consumer confidence will have much more knowledge of who will buy services. Companies that have the highest ratings and working tradition will certainly have greater sales of products, but if this company does not have adequate communication with customers, will miss the marketing of insurance products. 
Communication of insurance company with the customer aims to:

Consumer awareness

\section{Selling Product}

Maintaining consumer confidence The company`s communication with the customer is done through various means such as television, radio, daily newspapers, magazines, pamphlets, leaflets, publications, website, exhibitions, posters , sponsorships, etc. Bilboard.

\section{Advertising as a form of marketing:}

Advertising is an effective way to promote your products and services. When you advertise potential customers know who you are, where you are and what you can do for them. A successful advertising fields will spread the word around your products and services, attract customers and generate sales. If you try to encourage new customers to buy an existing product or a new service, there are many options from which to choose

\section{Good advertising should}

1. Build your business image;

2. Explain the benefits of your product and out services;

3. Increase the awareness for new products and services before, during and after the launch;

4. It generates interest in the market that aim, as well as a new audience of potential customers;

5. Encourage customers to ask about your business, increasing customer demand for your products.

Advertising is a vital part of any business operation, which in reality represents the tip of the iceberg in sales process. It can bring no more than a temporary success for an inferior product, but a very positive result for sale of products. We should be noted ad buyers or customers why they should buy your products, respectively in case of an insurance company products (insurance products). Advertising should be done regularly through various forms electronically, print or media. There are also other forms of marketing that affect virtually increase sales of products to businesses in Kosovo market, next we will mention in order to see the positive impact of marketing in realizing the goals of firms and increase the satisfaction of costumers.

In this paper we analyze forms of marketing in insurance companies as part Dardania Kosovo in the financial market, the company's campaign on television, radio, billboards, newspapers, magazines, flyers, internet and other forms used by the company.

\section{About the company}

Insurance Company "Dardania" entered in the insurance industry in 2000, with a temporary license by UNMIK, which became permanent from the Central Bank of Kosovo, in 2002. In 2010, the Insurance Company "Dardania" became part of Dukagjini Group, and more specifically its owner became z.Riza Luke. In late 2011, a new team of professionals, entrusted the management of the company, known for their successful experience in the insurance industry of Kosovo. During a short period, they were injected by the owner with significant financial value, which led to the repayment of old debts (inherited from the previous shareholders) at a total value of 4.5 million euro. Change not only the company provided financial support, but also brought a change in the mentality of the operation of the company, creating:

\section{A new organizational structure;}

Increase sales points (12 to 46) and accompanying infrastructure modernization of the company;

Evaluation of existing insurance products, bringing and has adapted to market requirements;

The establishment and licensing of new insurance products, bringing innovation to the market of Kosovo;

Contract with the Reinsurance company - a world leader in this market;

Contract with well-known companies - in the field of International Medical Assistance (covering health outside the territory of Kosovo); 
Insurance Company "Dardania" offers a variety of insurance products ranging from compulsory insurance GMTPL, followed by property insurance, insurance professional or health insurance and other types of insurance products, to be equaly competitive in the market. Dardania insurance productes offered in Kosovo insurance market are:

Personal Accident Insurance;

Health Insurance (group and family);

Travel Health Insurance;

Property insurance (fire and all other additional risks);

Providing Residential (apartments, residential houses);

Public Liability Insurance;

Product liability insurance;

Professional liability insurance;

Provision of all the risks during construction;

Provide money during transport;

Provide Cash in Safe;

Provision of Guarantee Bid;

Provision of Guarantee Contract (execution, and maintenance advance);

Providing own motor vehicle - CASCO;

Compulsory GMTPL;

Compulsory GMTPL Kosovo Plus (available for Macedonia);

Providing border.

Dardania advertisement in TV

Insurance Company Dardania its advertising in four main television stations in the country: RTK, KTV, RTV 21 and TV Dukagjini local television. Advertising this company on television mainly dealing with the promotion of their products, by publishing advertisements dealing in insurance mandatory: TPL and TPL - Plus, as well as voluntary insurance where they went: CASCO, insurance of property and assets - housing, health insurance, and other types of insurance

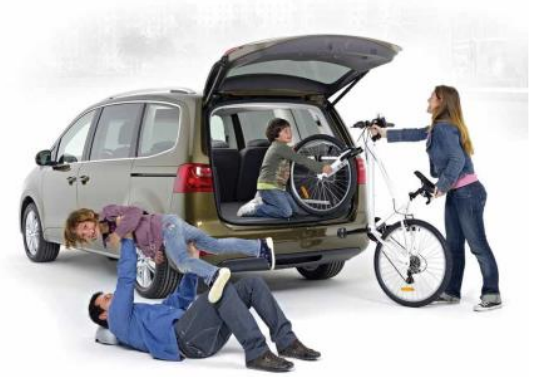

Advertisement broadcast advertising in the block during the transmission of any series or entertainment show. Advertising is over 26 seconds.

\section{Dardania advertisement in Radio}

Insurance Company "Dardania" markets in two main radio stations: Radio Kosova and Radio Dukagjini. Advertising text on radio is the same as that on television. Advertising usually transmitted to block advertising time, their duration is 26 and 27 seconds. Dardania Insurance Company is the sponsor of a radio show.

\section{Dardania advertisement on internet}

Usually one of the most popular format today to insurance companies are advertising through the internet, respectively various web sites such as Facebook on their official Web site on the Internet, etc. 


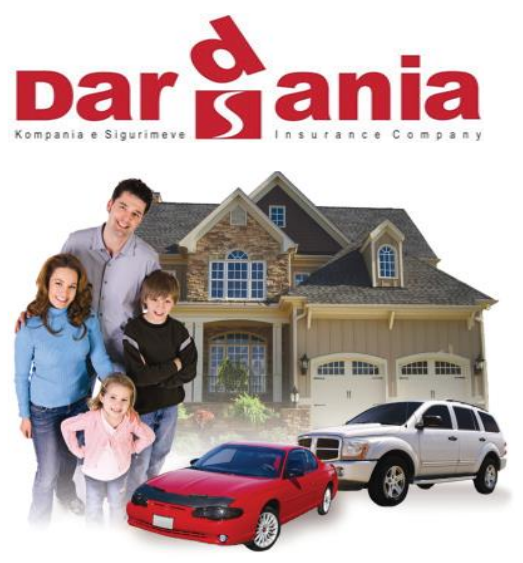

\section{Conclusions and reccomendations}

Research and promotion of sales of insurance products as an element of marketing in insurance, represents one of the most important segments in the field of marketing research in insurance. Exercising such research requires the construction of such sales channels of insurance services through which will be acceptable to the user or the insured.

Insurance products are products for sale, ever since such products are not produced, and therefore has no warehouse stocks of these products. An application for such products bear based on information available to the insured on the risks that can be posed.

Sales in the insurance market plays a key role to meet supply and demand, because insurance products are products that are not seen, not touched, but exist only in the form of pledges. Selling a promise requires confidence, a belief that the service provider will be realized if a loss occurs. To any other economic entity if we do not manufacturer or service such a type of product.

The media are a very important element in the promotion of insurance products. In countries with a high development of insurance marketing is a very high cost compared with other sectors in an insurance company.

Marketing in insurance plays a role in many fold, by one side makes promoted the insurance products, then raise the awareness of citizens about models of protection from risks, increase reliability to consumers, the cost of paying for the promise given by the insurer if the loss occurs, it will happen. Advertising plays an important role of insurance products placed on the market. The best ads by many respondents as the insurer by the insured is also "the damage to Rate Best and timely pay the damage."

In terms of a functioning modern enterprise market it is almost impossible without a strong marketing, knowing that any day now marketing is changing and being perfected thanks to the informative teknologjsë, visive means, electronic, print etc. In this regard, we can say that insurance companies it is impossible to exist without a successful marketing.

To achieve this concept insurance companies must meet the following recommendations:

Insurance companies must invest in different types of marketing, because marketing is a very important aspect so that the products or services to be closer to the customer. Various forms of promotion, advertisement and other forms of marketing, make your product or service with attractive for the client.

Marketing research should be done to increase the market opportunities, research competition in market conditions for marketing takes time and appropriate budgetary allocations.

Every insurance company must have a marketing strategy and a marketing plan that should be useful for the development of the company for marketing stimulates the sale, the sale depends on the existence of the company. Every time we have to be one step ahead of rival companies operating in the local market. 


\section{Literature}

[1] Bakraqi, Xh. (2004), Risk Management and Insurance, Prishtina- Kosova

[2] Gashi, Sh. (2013), Risk Management in the Insurance Market, Prishtina - Kosova

[3] Jakupi, A. (2008), Introduction to Marketing, Prishtina- Kosova

[4] Vërçuni, A \& Uldedaj, Gj (2009), ), Introduction to Marketing, Tirana- Albania

[5] Ceku, B \& Aliu, H \& Deari H (2011), Principles of Marketing, Tetova- Macedonia

[6] Guri, Rinald \& Gjoni, Elisabeta \& Dervishi, Anxhela, (2012) "Fundamentals in the Insurance ", Tiran,- Albania

[7] Kosovo Insurance Association, (2012), Periodic Newsletters, Bulletins, Nr. 1,

[8] www.bqk-ks.org

[9] www.dardaniainsurance.com

[10] Jobber, D (2010), Principles and Practices of Marketing, 6/2010, London, England 